\title{
Production of bioherbicide by Phoma sp. in a stirred-tank bioreactor
}

\author{
Thiarles Brun' ${ }^{1}$ Jéssica E. Rabuske ${ }^{2}$ Izelmar Todero ${ }^{1}$ Thiago C. Almeida ${ }^{1}$ • \\ Jair J. D. Junior ${ }^{1}$ - Gustavo Ariotti ${ }^{1}$ - Tássia Confortin ${ }^{1} \cdot$ Jonas A. Arnemann $^{2}$ \\ Raquel C. Kuhn ${ }^{1} \cdot$ Jerson V. C. Guedes $^{2} \cdot$ Marcio A. Mazutti $^{1}$ (I)
}

Received: 15 June 2016/Accepted: 20 October 2016/Published online: 27 October 2016

(c) The Author(s) 2016. This article is published with open access at Springerlink.com

\begin{abstract}
The objective of this work was to produce an herbicide by submerged fermentation in a stirred-tank bioreactor and to assess the potential herbicidal in preemergence, post-emergence, and in a detached leaves of Cucumis sativus var species. wisconsin (cucumber) and Sorghum bicolor (sorghum) species. Fermentations were carried out in a stirred-tank bioreactor with useful volume of $3 \mathrm{~L}$. Stirring rate $(40,50$, and $60 \mathrm{rpm})$ and aeration $(1,2$ and $3 \mathrm{vvm}$ ) were the variables studied for bioherbicide production. Fermented broth was fractioned with different solvents to identify the molecules produced by the fungus in a multi-dimensional gas chromatograph system. Bioherbicide showed $100 \%$ inhibition of germination of both species in the pre-emergence tests. From detached leaves tests were verified yellowish lesions in Cucumis sativus and necrotic lesions on leaves of Sorghum bicolor. Post-emergence test presented variation of the phytotoxicity from 25 to $66 \%$ for the species $C$. sativus and from 32 to $58 \%$ by $S$. bicolor. The metabolites produced by submerged fermentation of Phoma sp. presented activity in pre-emergence, post-emergence, and detached leaves of $C$. sativus and $S$. bicolor and it could be an alternative in the future for weed control.
\end{abstract}

Marcio A. Mazutti

mazutti@ufsm.br

1 Department of Chemical Engineering, Federal University of Santa Maria, Av. Roraima, 1000, Santa Maria, RS 97105-900, Brazil

2 Department of Crop Protection, Federal University of Santa Maria, Av. Roraima, 1000, Santa Maria, RS 97105-900, Brazil
Keywords Microorganisms · Secondary metabolites · Fermentation · Bioreactors

\section{Introduction}

In recent years, the market for organic foods is increasing as well as the concept of sustainable agriculture. The development of safe and eco-friendly herbicides is an emergent necessity to control weeds in these cultivations (Yang et al. 2014). Biological weed control strategies can potentially address this need and provide novel modes of action that will inhibit the growth of weeds that are resistant to more commonly used herbicides (Harding and Raizada 2015). Inundative biological control (which refers to the application of propagation of fungal spores or bacterial suspensions in concentrations that would not normally occur in nature with the intention of destroying a pest species within a managed area) is the strategy more employed (Bailey et al. 2011).

Although, a great number of microbial herbicide has been developed, only a few of them are available in commercial forms due to several constraints in the formulation, application, and commercialization. Biocontrol agents probably fail to be marketed internationally as these are living organisms and are fearful to introduce them from foreign countries (Chutia et al. 2007). For this reason, the future trend is the production of herbicidal compounds by fermentation, extract it from fermented broth, and use this compound in a more stable formulation. This strategy will not be limited on the continued survival of a given organism in an uncontrolled environment (Harding and Raizada 2015).

The use of microbial metabolites as bioherbicide is well reported in literature, especially for fungus of genera 
Phoma (Hubbard et al. 2015, 2016; Kalam et al. 2014; Bailey et al. 2013; Andolfi et al. 2013). In a previous study, we also have used Phoma sp. to produce a bioherbicide by solid-state fermentation (Klaic et al. 2016), with promising results. However, the scale-up of solid-state fermentation process is complicated due to difficult to remove the metabolic heat generated during the process (Mazutti et al. 2010). One possibility is the production of bioherbicide by submerged fermentation, which is a process well established industrially. However, it is necessary to evaluate the influence of process variables such as stirring rate and agitation on metabolite production, because biosynthesis of active secondary metabolites by fungi occurs as a specific response to the different growing environments (Bracarense and Takahashi 2014). It is well documented that stirring rate affects severally the growth of microorganism due to shear stress (Serrano-Carreón et al. 2015; GarciaOchoa et al. 2013; Maldonado et al. 2012). So, it is necessary to select appropriate levels for these variables in bench-scale bioreactors before scale-up the process (Formentini et al. 2014).

Based on these aspects, the present study investigates the bioherbicide production by Phoma sp. in a stirred-tank bioreactor containing liquid media. Stirring rate (40, 50, and $60 \mathrm{rpm}$ ) and aeration (1, 2 and $3 \mathrm{vvm}$ ) were the variables studied. Different bioassays were applied to assess the herbicidal activity of fermented broth without cells in pre-emergence, post-emergence, and in detached leaves of $C$. sativus and $S$. bicolor. In the assay with maximum herbicidal activity, the molecules produced were fractioned with different solvents and further identified in a multidimensional gas chromatograph system.

\section{Materials and methods}

\section{Materials}

Corn steep liquor (CSL) was obtained from Ingredion (Mogi Guaçu, SP, Brazil) and sucrose (Cristal) was purchased in a local market. All other chemicals, namely, $\left(\mathrm{NH}_{4}\right)_{2} \mathrm{SO}_{4}, \mathrm{FeSO}_{4} \cdot 7 \mathrm{H}_{2} \mathrm{O}, \mathrm{MnSO}_{4} \cdot \mathrm{H}_{2} \mathrm{O}$, and $\mathrm{MgSO}_{4}$, were purchased from Sigma-Aldrich.

\section{Microorganism, inoculum, and fermentations}

The strain of Phoma sp. (NRRL 43879) was obtained at the National Center for Agricultural Utilization ResearchEUA (ARS). It was maintained in a potato dextrose agar (PDA) at $4{ }^{\circ} \mathrm{C}$ and subcultured every 15 days. Cell production for inoculum was incubated in a Petri dish containing PDA for 8 days at $28^{\circ} \mathrm{C}$. Afterwards, a disk of $6 \mathrm{~mm}$ of fungal mycelium was transferred to an
Erlenmeyer flask containing $100 \mathrm{~mL}$ of fermentation medium at $28{ }^{\circ} \mathrm{C}, 120 \mathrm{rpm}$ for 5 days (Innova 44R, NewBrunswick) for inoculum.

The fermentations were carried out in a batch bioreactor (BIOTEC-C, Tecnal, Brazil), containing 3.0 L of the culture medium. Fermentations were started using $10 \%$ (V/V) of inoculum at an initial $\mathrm{pH}$ of $6.0,28{ }^{\circ} \mathrm{C}$ for 7 days. The fermentation medium was composed of corn steep liquor $(10 \% \mathrm{v} / \mathrm{v})$, sucrose $\left(20 \mathrm{~g} \mathrm{~L}^{-1}\right),\left(\mathrm{NH}_{4}\right)_{2} \mathrm{SO}_{4}\left(2 \mathrm{~g} \mathrm{~L}^{-1}\right)$, $\mathrm{MgSO}_{4} \cdot 7 \mathrm{H}_{2} \mathrm{O}\left(0.5 \mathrm{~g} \mathrm{~L}^{-1}\right), \mathrm{FeSO}_{4} \cdot 7 \mathrm{H}_{2} \mathrm{O}\left(1 \mathrm{~g} \mathrm{~L}^{-1}\right)$, and $\mathrm{MnSO}_{4} \cdot \mathrm{H}_{2} \mathrm{O}\left(1 \mathrm{~g} \mathrm{~L}^{-1}\right)$. Biomass was separated from fermentation broth by filtration using filter paper (Whatman number 2) followed by centrifugation (Eppendorf, model $5804 \mathrm{R}$ ) at $10,000 \mathrm{rpm}$ for $10 \mathrm{~min}$ and the supernatant was used in the bioassays.

The effect of aeration and stirring rate on herbicidal activity was evaluated by means of a central composite design (CCD) with four assays plus three central points. The range of variables investigated was 40-60 rpm and 1-3 vvm and the range was defined on preliminary tests. Each fermentation was considered as one treatment in the bioassay. The responses evaluated were the inhibition of germination in pre-emergence, phytotoxicity in postemergence, and in the punctured detached leaves.

\section{Bioassays}

Three different bioassays were carried out to investigate the herbicidal activity of fermented broth without cells: pre-emergence, post-emergence, and detached leaves of Cucumis sativus var. Wisconsin and Sorghum bicolor.

\section{Pre-emergence}

The germination tests were carried by applying $10 \mathrm{~mL}$ of fermented broth without the cells in a germitest paper containing 25 seeds of each culture and maintained at $25{ }^{\circ} \mathrm{C}$ (POL-EKO, model KK 350). Control tests were carried out replacing fermented broth by culture media and distilled water. The seed germination was evaluated at 4 (first count) and 10 (second count) days after the application of bioherbicide, according to Brazilian rules for seed analysis (Brasil 2009). Afterwards, the germinated or nongerminated seeds were counted. All seeds that presented the primary root protrusion higher than $2 \mathrm{~mm}$ were considered as germinated. Each treatment was replicated four times.

\section{Punctured leaf assay}

The phytotoxic effects of the fermented broth without cells were assessed by a punctured leaf assay. Well-expanded leaves of 2-week-old $C$. sativus e $S$. bicolor plants grown in 
a greenhouse were punctured (base, summit, and center) using a sterile fine-pointed needle, and droplets $(1 \mu \mathrm{L})$ of each treatment solution were deposited on each of these sites ( 2 punctures per leaf, 3 leaves per solution). After droplet application, the plants were maintained at $25{ }^{\circ} \mathrm{C}$ (POL-EKO, model KK 350) with photoperiod of $12 \mathrm{~h}$, and the diameter of the lesions was measured after $72 \mathrm{~h}$.

\section{Post-emergence}

The herbicidal activity was determined using $C$. sativus and S. bicolor as target plants. A completely randomized design composed of eight treatments (each fermentation of $\mathrm{DCC}+\mathrm{a}$ control) and four repetitions, where each repetition was represented for a tray containing four plastic cups with volume of $200 \mathrm{~mL}$ with commercial substrate $\left(\right.$ Macplant ${ }^{\circledR}$ ) without any treatment. Three seeds were sown in each vessel, and after the emergence, only one plant was maintained in each vessel and cultivated for 7 days in a greenhouse located at the Federal University of Santa Maria (Santa Maria, Brazil).

A volume of $50 \mathrm{~mL}$ of fermented broth was applied at the same time in each bioassay using a garden sprayer. Control assays were performed using the culture medium instead fermented broth, and also using distilled water. Seven days after the application, plant injury was visually estimated as percent growth reduction by comparing to untreated controls, where $100 \%$ represents complete plant death and $0 \%$ represents no effect (Frans and Crowley, 1986). In addition, we investigated other factors such as (1) height of plants; (2) fresh weight of aerial and root parts; and (3) dry weight of aerial and root parts.

\section{Liquid-liquid extraction of molecules}

Liquid-liquid extractions were carried out mixing $50 \mathrm{~mL}$ of fermented broth without cells with $50 \mathrm{~mL}$ of organic solvents with different polarities (methanol, ethanol, and ethyl acetate) in an equilibrium jacketed glass cells $(100 \mathrm{~mL})$. The extractions were carried out at $10{ }^{\circ} \mathrm{C}$ using a thermostatic bath (Quimis, Brazil) under magnetic stirring (Ika Werke, model RH-KT/C, Staufen, Germany) to promote agitation of the mixture during $12 \mathrm{~h}$. After this procedure, the phases were separated and the organic solvent fraction was used for chemical identification of the compounds in a gas chromatograph.

\section{Identification of molecules by multi-dimensional gas chromatograph system}

The molecules produced by the fungus were determined using a multi-dimensional gas chromatograph system (Shimadzu, model MDGC/GCMS-2010) equipped with a mass spectrometer detector (QP-2010 Ultra) and flame ionization detector (FID-2010 Plus), and automatic injection system (AOC-20i). A volume of $1 \mu \mathrm{L}$ of samples was injected in split mode $(30: 1)$ at $250^{\circ} \mathrm{C}$. The separation of compounds was carried out in a capillary column Rtx-1 MS $(30 \mathrm{~m} \times 0.32 \mathrm{~mm} \times 0.1 \mu \mathrm{m})$. Helium was the carrier gas with a flow rate of $2 \mathrm{~mL} \mathrm{m^{-1 }}$ at a pressure of $5.05 \mathrm{psi}$; electronic impact mode of $70 \mathrm{eV}$. Initial temperature of the column was set at $70{ }^{\circ} \mathrm{C}$ which was increased up to $250{ }^{\circ} \mathrm{C}$ at a rate of $3{ }^{\circ} \mathrm{C} \min ^{-1}$ and kept isothermal for $10 \mathrm{~min}$. The temperature of detector was set at $250{ }^{\circ} \mathrm{C}$. The compounds were identified by comparison of the mass spectrum with those of database (Wiley, $9^{\circ}$ Edition).

\section{Statistical analysis}

All statistical analysis were performed using Statistica 8.0 software (Statsoft Inc., Tulsa, OK, USA), considering a 95\% significance level. Statistical differences between treatments were determined by one-way analysis of variance and means separated using the least significant difference test $(p<0.05)$.

\section{Results and discussion}

Table 1 presents the results obtained in the bioassays with C. sativus and S. bicolor for all runs of CCD (T1-T7) and also for the control treatment (T0). In the pre-emergence, all treatments of CCD showed inhibitory effect on germination of $C$. sativus and S. bicolor in the first and second count, where in the second count the inhibition of germination was $100 \%$ for all treatments of CCD. On the other hand, the control treatment presented $100 \%$ of germination for the two species. In the first count, the treatment that caused the largest interference in the germination of $C$. sativus was $\mathrm{T} 4$, with $40 \%$ inhibition of germination, whereas for S. bicolor it was T6, with $84 \%$ inhibition. The metabolites produced by Phoma sp. have a broad herbicidal action spectrum in pre-emergence, since they have effect on the group of monocotyledonous ( $S$. bicolor) and dicotyledonous plants (C. sativus). This result is slightly different than those reported by Bailey et al. (2011), which produced a bioherbicide with Phoma sp. and obtained a better effect on dicotyledonous seeds than in monocotyledons. The variables investigated did not affect the herbicidal activity in pre-emergence, since total inhibition was obtained for both species independent of stirring and aeration rates employed.

Results for punctured leaf assay demonstrated the occurrence of injuries as mild yellowing and light necrosis in detached leaves of $C$. sativus and S. bicolor, respectively. These spots were observed on the first day after the 
Table 1 Influence of process variables on the inhibitory effect of fermented broth of Phoma sp. in the different bioassay

\begin{tabular}{|c|c|c|c|c|c|c|c|c|c|c|}
\hline \multirow[t]{3}{*}{ Treatments } & \multirow{3}{*}{$\begin{array}{l}\text { Stirring rate } \\
(\mathrm{rpm})\end{array}$} & \multirow{3}{*}{$\begin{array}{l}\text { Aeration rate } \\
\text { (vvm) }\end{array}$} & \multicolumn{4}{|c|}{ Pre-emergence } & \multicolumn{2}{|c|}{ Punctured leaf } & \multicolumn{2}{|c|}{ Post-emergence } \\
\hline & & & \multicolumn{2}{|l|}{ C. sativus } & \multicolumn{2}{|c|}{ S. bicolor } & \multirow{2}{*}{$\begin{array}{l}\text { C. } \\
\text { sativus }\end{array}$} & \multirow{2}{*}{$\begin{array}{l}\text { S. } \\
\text { bicolor }\end{array}$} & \multirow{2}{*}{$\begin{array}{l}\text { C. } \\
\text { sativus }\end{array}$} & \multirow{2}{*}{$\begin{array}{l}S . \\
\text { bicolor }\end{array}$} \\
\hline & & & $\begin{array}{l}1^{\circ} \text { count } \\
(\%)\end{array}$ & $\begin{array}{l}2^{\circ} \text { count } \\
(\%)\end{array}$ & $\begin{array}{l}1^{\circ} \text { count } \\
(\%)\end{array}$ & $\begin{array}{l}2^{\circ} \text { count } \\
(\%)\end{array}$ & & & & \\
\hline T0 & - & - & $0^{\mathrm{ba}}$ & $0^{\mathrm{b}}$ & $0^{\mathrm{c}}$ & $0^{\mathrm{b}}$ & $\mathrm{N}^{*}$ & $\mathrm{~N}$ & $0 d^{b}$ & $0^{\mathrm{c}}$ \\
\hline $\mathrm{T} 1$ & $40(-1)$ & $1(-1)$ & $12^{\mathrm{a}}$ & $100^{\mathrm{a}}$ & $55^{\mathrm{b}}$ & $100^{\mathrm{a}}$ & - & + & $49.4^{\mathrm{b}}$ & $58.1^{\mathrm{a}}$ \\
\hline $\mathrm{T} 2$ & $60(1)$ & $1(-1)$ & $24^{\mathrm{a}}$ & $100^{\mathrm{a}}$ & $81^{\mathrm{a}}$ & $100^{\mathrm{a}}$ & - & + & $25.0^{\mathrm{c}}$ & $43.1^{\mathrm{b}}$ \\
\hline $\mathrm{T} 3$ & $40(-1)$ & $3(1)$ & $29^{\mathrm{a}}$ & $100^{\mathrm{a}}$ & $61^{\mathrm{b}}$ & $100^{\mathrm{a}}$ & - & + & $66.9^{\mathrm{a}}$ & $41.2^{\mathrm{b}}$ \\
\hline $\mathrm{T} 4$ & $60(1)$ & $3(1)$ & $40^{\mathrm{a}}$ & $100^{\mathrm{a}}$ & $72^{\mathrm{a}}$ & $100^{\mathrm{a}}$ & - & ++ & $65.0^{\mathrm{a}}$ & $58.1^{\mathrm{a}}$ \\
\hline T5 & $50(0)$ & $2(0)$ & $16^{\mathrm{a}}$ & $100^{\mathrm{a}}$ & $51^{\mathrm{b}}$ & $100^{\mathrm{a}}$ & - & + & $61.2^{\mathrm{a}}$ & $32.5^{\mathrm{b}}$ \\
\hline T6 & $50(0)$ & $2(0)$ & $12^{\mathrm{a}}$ & $100^{\mathrm{a}}$ & $84^{\mathrm{a}}$ & $100^{\mathrm{a}}$ & - & + & $56.9^{\mathrm{a}}$ & $40.6^{\mathrm{b}}$ \\
\hline $\mathrm{T} 7$ & $50(0)$ & $2(0)$ & $26^{\mathrm{a}}$ & $100^{\mathrm{a}}$ & $80^{\mathrm{a}}$ & $100^{\mathrm{a}}$ & - & + & $45.6^{\mathrm{b}}$ & $39.4^{\mathrm{b}}$ \\
\hline
\end{tabular}

a, b Different letters in the column represent a significant difference at 95\% ( $p<0.05$-Tukey test)

$* N$ without effect, - light chlorosis, - sharp chlorosis, + light necrosis, ++ sharp necrosis

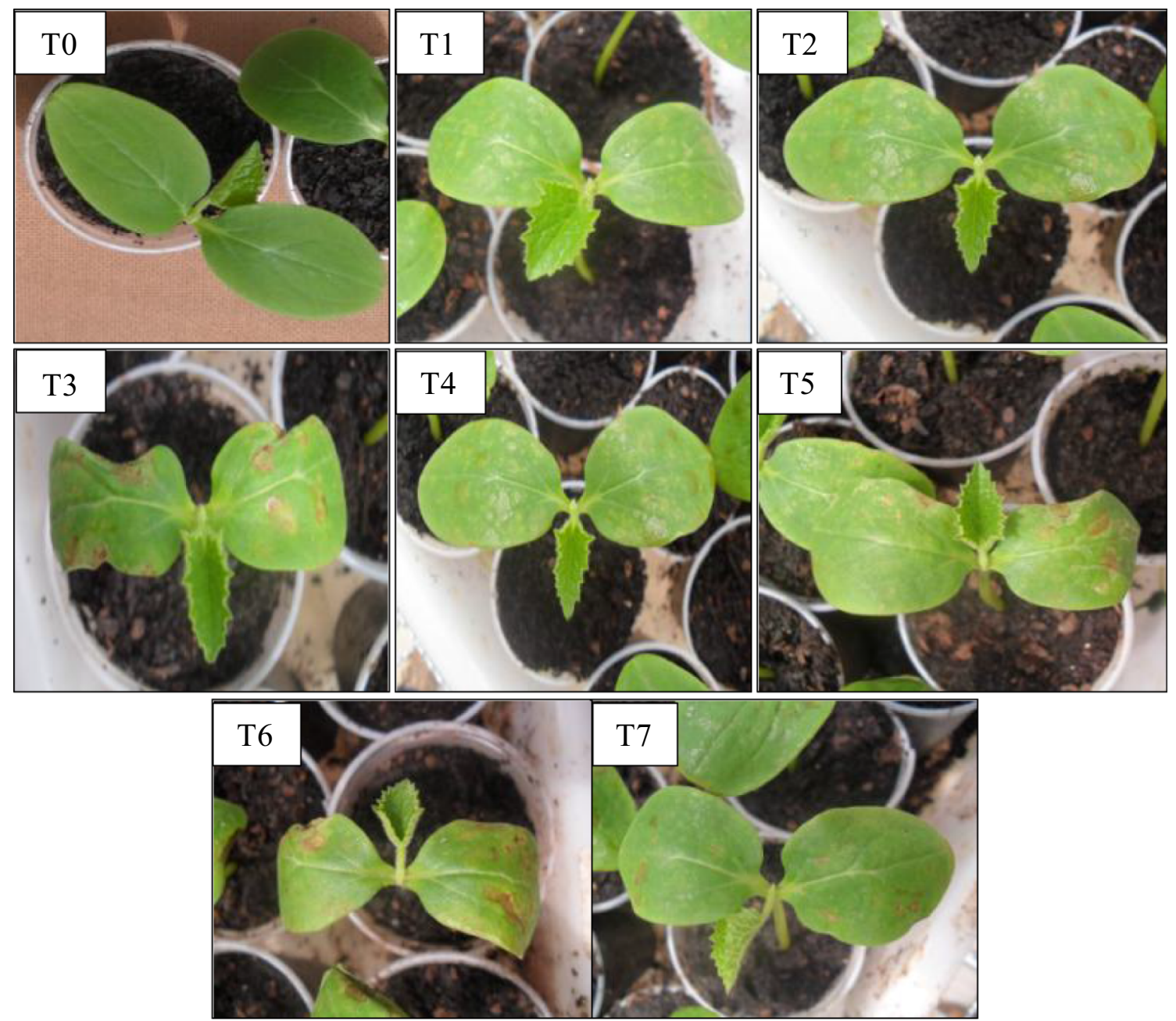

Fig. 1 Photograph illustrating the lesions caused by the fermented broth of Phoma sp. in C. sativus

evaluation and intensified until the last evaluation, which was performed $72 \mathrm{~h}$ after the treatment application. The most pronounced damage was found in the treatment $\mathrm{T} 3$ for C. sativus and T4 for S. bicolor, showing severe chlorosis of leaves of $C$. sativus and severe necrosis for $S$. bicolor. The injury verified in our work for the punctured 

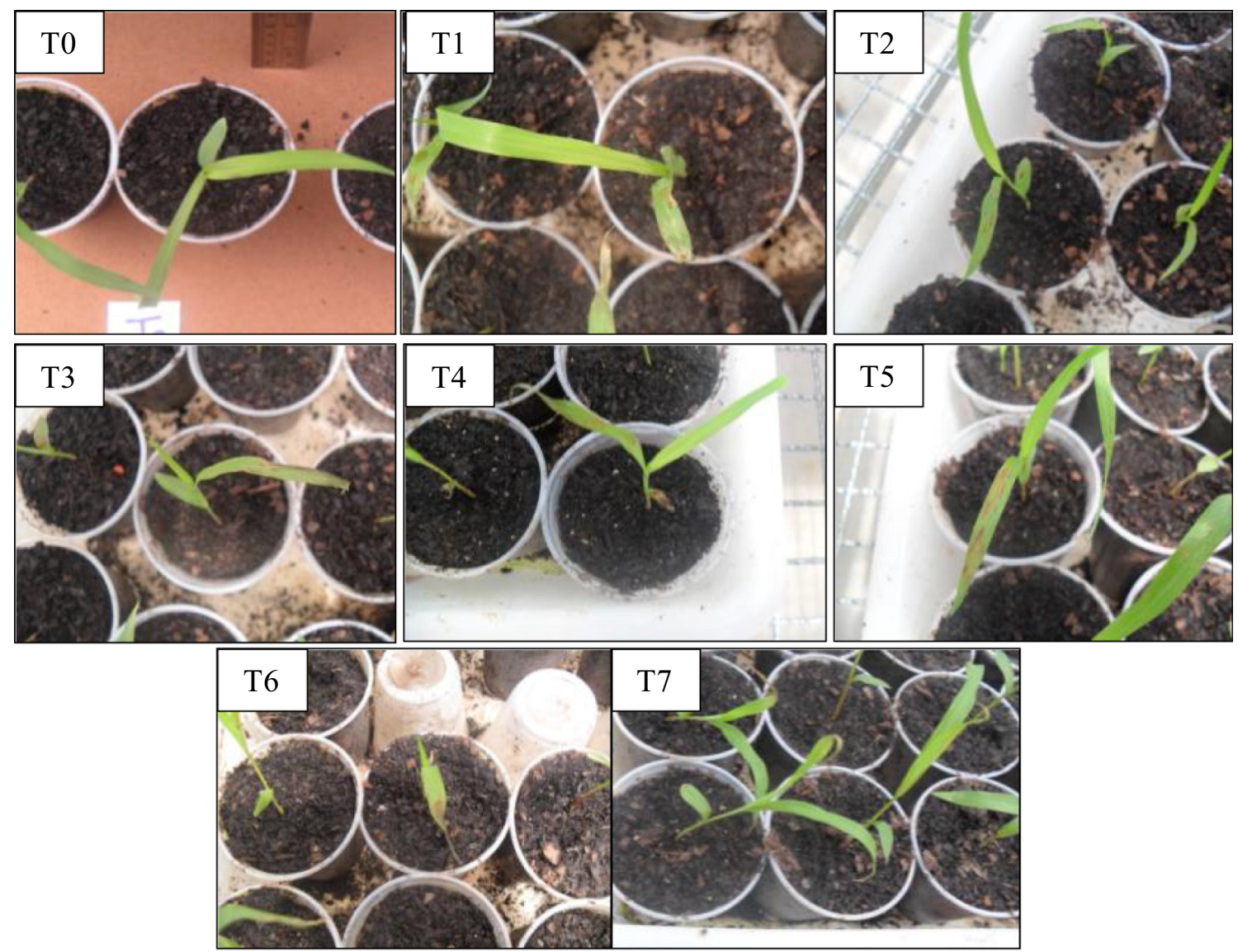

Fig. 2 Photograph illustrating the lesions caused by the fermented broth of Phoma sp. in S. bicolor

leaf assay is in good agreement with other studies for Phoma species. Vikrant et al. (2006) applied filtered broth of Phoma herbarum obtained by submerged fermentation on detached leaves of Parthenium hysterophorus (ragweed) and verified fast yellowing followed by necrosis and death of the leaves $48 \mathrm{~h}$ after treatment. Using a puncture test, made with leaves of Stellaria media, Urtica dioica, Sonchus arvensis, Parietaria officinalis, Lactuca serriola, and Helianthus annuus, the metabolites produced by the fungus Phoma chenopodiicola caused chlorosis and necrosis in the leaves of these species (Evidente et al. 2015).

The results obtained in punctured detached leaves of $C$. sativus and S. bicolor showed the incidence of chlorosis or necrotic lesions, but with low intensity. So the detached leaf bioassay was not considered significant to choose the best condition for production of metabolites with herbicidal action. The low effect verified may be related to the low concentration of metabolites present in fermented broth without the addition of adjuvant to improve the efficacy. Varejão et al. (2013) reported that the phytotoxins are often present in low concentrations in the filtrate coming from the fermentation processes of microorganisms.
For post-emergence bioassays, the treatments that presented the highest percentage of phytotoxicity for C. sativus were $\mathrm{T} 3(66.8 \%), \mathrm{T} 4(65.0 \%), \mathrm{T} 5(61.2 \%)$, and $\mathrm{T} 6$ $(56.8 \%)$, while for S. bicolor the best results were found in $\mathrm{T} 1(58.1 \%)$ and $\mathrm{T} 4(58.1 \%)$. In these treatments there are no statistical difference according to the Scott-Knott test $(p<0.05)$.Although no significant statistical differences among treatments were found, the greatest potential phytotoxic on the species assessed was $\mathrm{T} 3$ and $\mathrm{T} 4$ for $C$. sativus and S. bicolor, respectively (Figs. 1,2). The plants for the control test did not have phytotoxicity, demonstrating that the injury is due to the presence of compound (or compounds) in the fermented broth. Figure 1 and 2 show the damage caused by the application of fermented broth of Phoma sp. on the leaves ranged from a slight chlorosis until wilted appearance or necrotic lesions. Vikrant et al. (2006) applied the filtered broth of Phoma herbarum and observed damage such as yellowing, followed by sharp withers and complete collapse of seedlings Parthenium hysterophorus (ragweed). Cimmino et al. (2013) tested the potential of chenopodolin metabolite produced by the fungus Phoma chenopodicola in Cirsium arvense and Setaria viride (monocotyledon and 

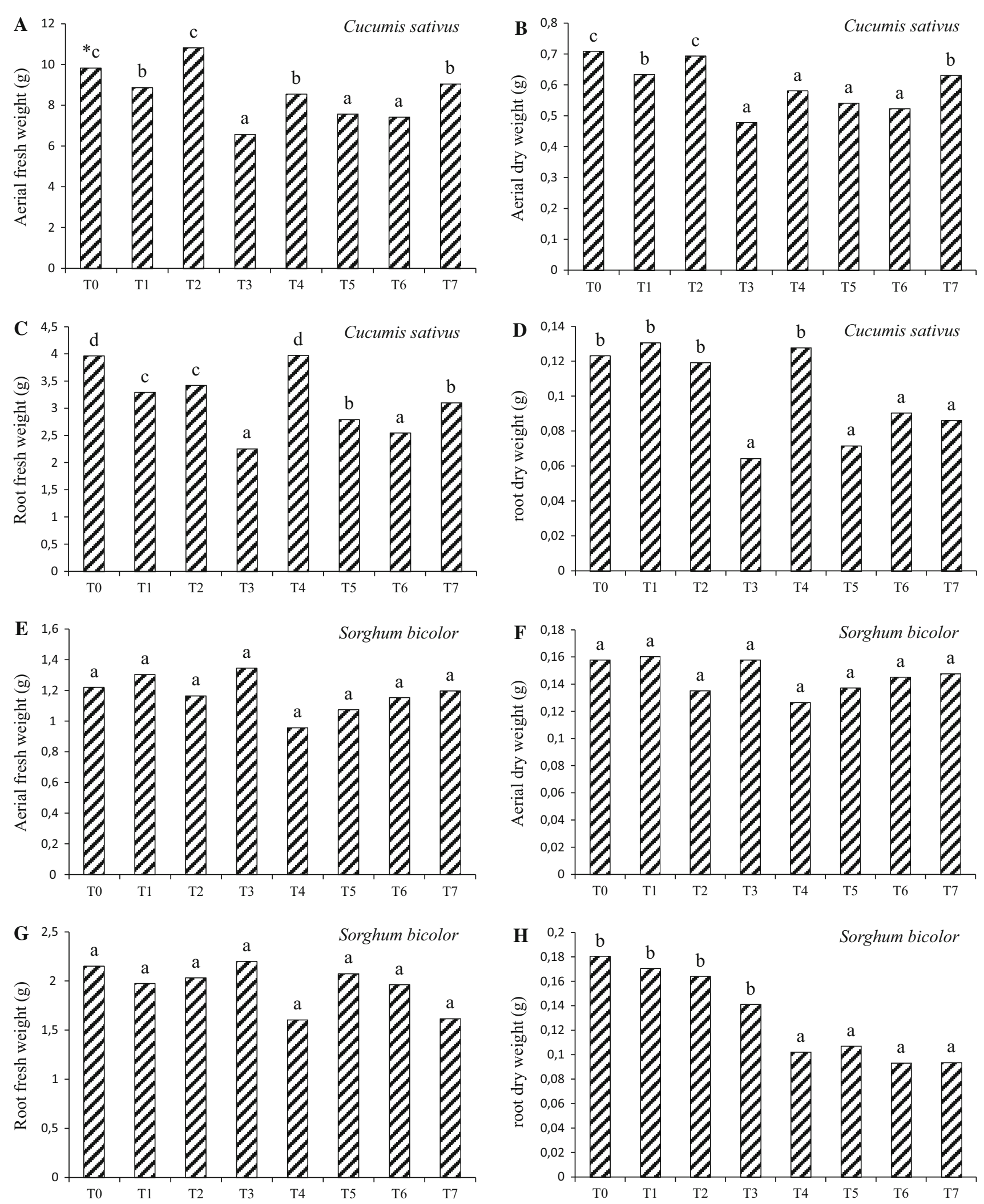

Fig. 3 Fresh and dry weight of aerial and root parts of $C$. sativus and S. bicolor obtained in the treatments. Different letters represent a significant difference at $95 \%(p<0.05$-Tukey test $)$ 

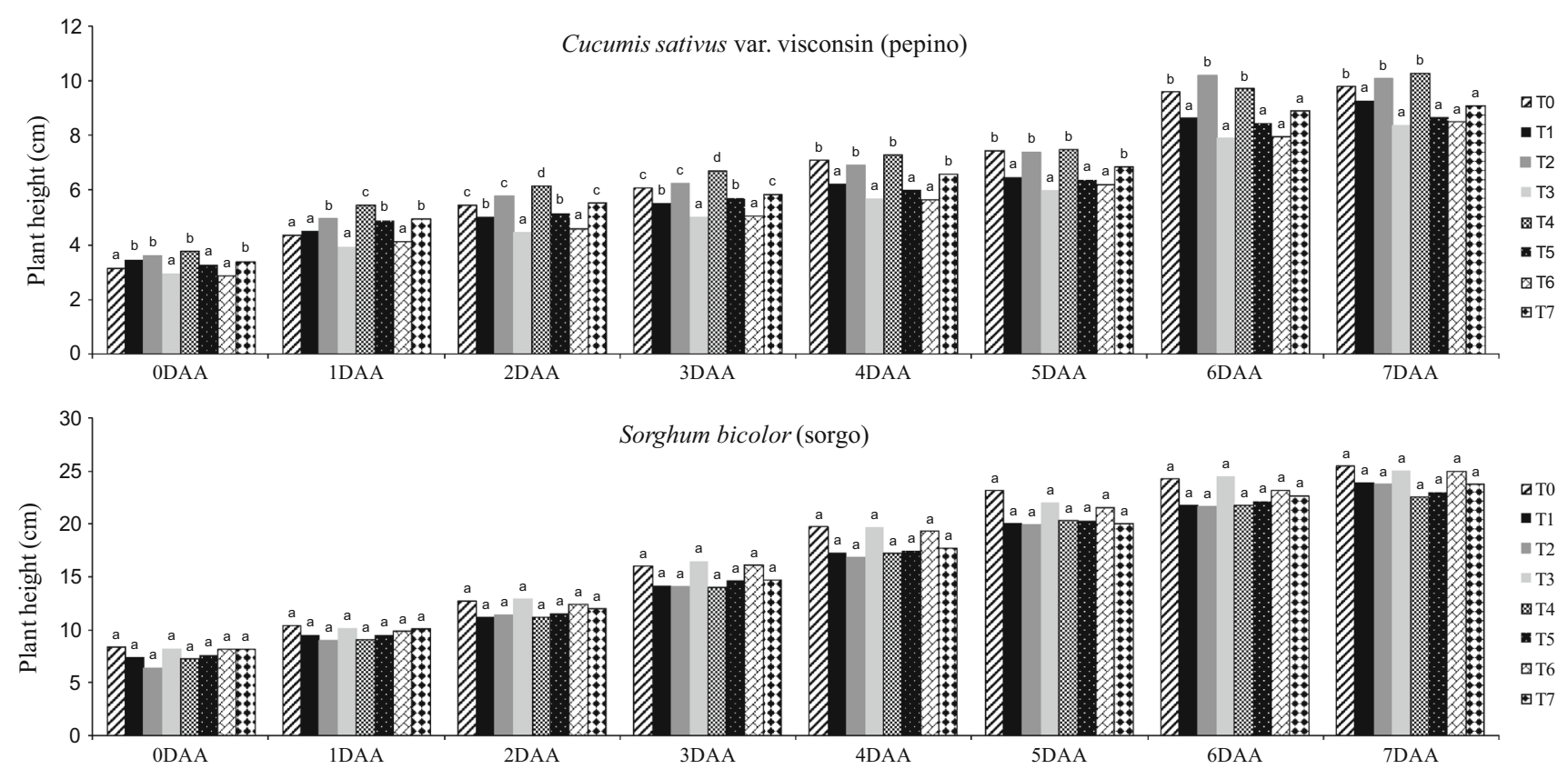

Fig. 4 Height of plants evaluated daily during 7 days. Different letters represent a significant difference at $95 \%(p<0.05$-Tukey test)

Table 2 Chemical profile obtained in treatment T3

\begin{tabular}{|c|c|c|c|c|c|}
\hline & Compound & Chemical structure & RT & Área (ua) & $\%$ Normalized area \\
\hline \multicolumn{6}{|c|}{ Methanol } \\
\hline 1 & 2-Oxiraneethanol, 2-t-butyldimethysilyloxymethyl- acetate & $\mathrm{C} 13 \mathrm{H} 26 \mathrm{O} 4 \mathrm{Si}$ & 9.077 & 24,551 & 1.088 \\
\hline 2 & Acetate, [3-(acetyloxy)-4,5-dihydro-5-isoxazolyl]methyl & C8H11NO5 & 11.117 & 19,396 & 0.86 \\
\hline 3 & 1,4-Diacetyl-3-acetoxymethyl-2,5-methylene-1-rhamnitol & $\mathrm{C} 14 \mathrm{H} 22 \mathrm{O} 8$ & 11.485 & 186,646 & 8.273 \\
\hline 4 & Uric acid & $\mathrm{C} 5 \mathrm{H} 4 \mathrm{~N} 4 \mathrm{O} 3$ & 11.518 & 15,193 & 0.673 \\
\hline 5 & Spermine & $\mathrm{C} 10 \mathrm{H} 26 \mathrm{~N} 4$ & 11.548 & 10,497 & 0.465 \\
\hline 6 & 12-Methyl-oxa-cyclododecan-2-one & $\mathrm{C} 12 \mathrm{H} 22 \mathrm{O} 2$ & 11.594 & 16,766 & 0.743 \\
\hline 7 & 3,7-Diazabicyclo[3.3.1]nonane, 9,9-dimethyl- & C9H18N2 & 11.778 & 128,511 & 5.696 \\
\hline 9 & Pyrrolo[1,2-a]pyrazine-1,4-dione, hexahydro-3-(2-methylpropyl)- & $\mathrm{C} 11 \mathrm{H} 18 \mathrm{~N} 2 \mathrm{O} 2$ & 12.547 & $1,454,291$ & 64.463 \\
\hline 10 & 12-Dimethylamino-10-oxododecanoic acid & $\mathrm{C} 14 \mathrm{H} 27 \mathrm{NO} 3$ & 12.666 & 400,130 & 17.736 \\
\hline \multicolumn{6}{|c|}{ Ethanol } \\
\hline 1 & Methyl 4,6-decadienyl ether & $\mathrm{C} 11 \mathrm{H} 20 \mathrm{O}$ & 11.147 & 6864 & 0.548 \\
\hline 2 & 3-Trifluoroacetoxydodecane & $\mathrm{C} 14 \mathrm{H} 25 \mathrm{~F} 3 \mathrm{O} 2$ & 11.316 & 26,446 & 2.11 \\
\hline 3 & 5-Dodecanol acetate & $\mathrm{C} 14 \mathrm{H} 28 \mathrm{O} 2$ & 11.58 & 30,363 & 2.423 \\
\hline 4 & Pyrrolo[1,2-a]pyrazine-1,4-dione, hexahydro- & $\mathrm{C} 7 \mathrm{H} 10 \mathrm{~N} 2 \mathrm{O} 2$ & 11.612 & 64,921 & 5.18 \\
\hline 5 & 3,7-Diazabicyclo[3.3.1]nonane, 9,9-dimethyl- & C9H18N2 & 11.809 & 21,095 & 1.683 \\
\hline 6 & Pyrrolo[1,2-a]pyrazine-1,4-dione, hexahydro-3-(2-methylpropyl)- & $\mathrm{C} 11 \mathrm{H} 18 \mathrm{~N} 2 \mathrm{O} 2$ & 12.559 & $1,103,547$ & 88.056 \\
\hline \multicolumn{6}{|c|}{ Ethyl acetate } \\
\hline 1 & Pyrrolo[1,2-a]pyrazine-1,4-dione, hexahydro-3-(2-methylpropyl)- & $\mathrm{C} 11 \mathrm{H} 18 \mathrm{~N} 2 \mathrm{O} 3$ & 12.699 & 18,577 & 43.020 \\
\hline 2 & 2,2-Dipropyl-N-ethylpiperidine & $\mathrm{C} 13 \mathrm{H} 27 \mathrm{~N}$ & 12.778 & 15,358 & 35.564 \\
\hline
\end{tabular}

$R T$ retention time

dicotyledonous, respectively), verifying injuries as necrosis, wilting, and tissue degradation in general.

The fresh and dry weight of aerial and root parts of plants at 7 days after the application of fermented broth are showed in Fig. 3. For C. sativus, the treatment T3 reduced fresh and dry weight of aerial and root parts. For S. bicolor, the highest inhibitory effect was observed in T4, reducing also the fresh and dry weight of aerial and root parts. 
Table 3 Chemical profile obtained in treatment T4

\begin{tabular}{|c|c|c|c|c|c|}
\hline & Compound & Chemical structure & RT & Área (ua) & $\%$ Normalized area \\
\hline \multicolumn{6}{|c|}{ Methanol } \\
\hline 1 & 3-Trifluoroacetoxydodecane & $\mathrm{C} 14 \mathrm{H} 25 \mathrm{~F} 3 \mathrm{O} 2$ & 11.1 & 10,502 & 0.01 \\
\hline 2 & Pyrrolo[1,2-a]pyrazine-1,4-dione, hexahydro- & $\mathrm{C} 7 \mathrm{H} 10 \mathrm{~N} 2 \mathrm{O} 2$ & 11.4 & 129,668 & 0.19 \\
\hline 3 & $\begin{array}{l}\text { Pyrrolo[1,2-a]pyrazine-1,4-dione, hexahydro-3-(2- } \\
\text { methylpropyl)- }\end{array}$ & $\mathrm{C} 11 \mathrm{H} 18 \mathrm{~N} 2 \mathrm{O} 2$ & 12.5 & $1,278,230$ & 1.89 \\
\hline 4 & Hydroquinine, $2^{\prime}$-propoxy- & $\mathrm{C} 23 \mathrm{H} 32 \mathrm{~N} 2 \mathrm{O} 3$ & 18.6 & $5,712,157$ & 84.44 \\
\hline 5 & Acetic acid, 3-acetoxy-5-pentyl-2-(4,6,6-trimethylbicyclo[3.1.] & $\mathrm{C} 25 \mathrm{H} 34 \mathrm{O} 4$ & 22.3 & $9,104,318$ & 13.45 \\
\hline \multicolumn{6}{|c|}{ Ethanol } \\
\hline 1 & Uric acid & C5H4N4O4 & 11.7 & 699,460 & 19.92 \\
\hline 2 & Pyrrolo[1,2-a]pyrazine-1,4-dione, hexahydro- & C7H10N2O2 & 12.4 & $2,328,303$ & 66.31 \\
\hline 3 & 1-Undecanethiol & $\mathrm{C} 11 \mathrm{H} 24 \mathrm{~S}$ & 12.6 & 456,483 & 13.00 \\
\hline 4 & 3,7-Diazabicyclo[3.3.1]nonane, 9,9-dimethyl- & C9H18N2 & 15.3 & 14,231 & 0.405 \\
\hline 5 & Pregn-4-ene-3,20-dione, 17,21-dihydroxy-, bis(O-methyloxime) & $\mathrm{C} 23 \mathrm{H} 36 \mathrm{~N} 2 \mathrm{O} 4$ & 16.1 & 12,601 & 0.359 \\
\hline \multicolumn{6}{|c|}{ Ethyl acetate } \\
\hline 1 & 2,4,7-Trioxabicyclo[4.4.0]dec-9-ene, 8-decyloxy-3-phenyl- & $\mathrm{C} 23 \mathrm{H} 34 \mathrm{O} 4$ & 12.0 & 7,694 & 33.48 \\
\hline 2 & $\begin{array}{l}\text { Pyrrolo[1,2-a]pyrazine-1,4-dione, hexahydro-3-(2- } \\
\text { methylpropyl)- }\end{array}$ & $\mathrm{C} 11 \mathrm{H} 18 \mathrm{~N} 2 \mathrm{O} 2$ & 12.7 & 11,368 & 49.46 \\
\hline
\end{tabular}

$R T$ retention time

Figure 4 presents the results of referring to variation of plant height among the treatments assessed daily during 7 days after application. No significant difference between T3 and T6 treatments were observed for $C$. sativus. However, the highest herbicidal effect was observed in T3, causing a reduction in plant height. For $S$. bicolor, no significant difference $(p<0.05)$ between treatments also was observed, however, the treatment T4 showed the highest reduction in the growth.

The best results were obtained in T3 for $C$. sativus and T4 for S. bicolor. The difference in T3 and T4 was the stirring rate (40 and $60 \mathrm{rpm}$, respectively) both at $3 \mathrm{vvm}$. Modification of process variables as stirring rate may affect the excretion of different compounds in the media, because biosynthesis of active secondary metabolites by fungi occurs as a specific response to the different growing environments (Bracarense and Takahashi, 2014). This is corroborated by comparing the chemical composition of $\mathrm{T} 3$ and T4 experiments (Tables 2, 3, respectively), where the profile and the concentration (expressed as normalized peak area) were different.

Some compounds were found more frequently in both analyzed fractions, highlighting the pyrrolo [1,2-a] pyrazine1,4-dion, Hexahydro-3-(2-methylpropyl) that were observed in greater abundance for most of the analyzed fractions, always having the largest peak area. These compounds have similarities with two other phytotoxic metabolites from $\mathrm{Al}$ ternaria alternata with herbicidal activity, namely, Maculosin-1 \{(I) (3S-cis) -3-hexahydro- [(4-hydroxyphenyl) methyl] pyrrolo [1,2-a] pyrazine -1,4-dione $\}$, and
Maculosin-2 \{(II) (3S-cis) hexahydro-3-methyl-phenyl pyrrolo [1,2-a] pyrazine-1,4-dione\} (Bobylev et al. 2000). An herbicide which has a pyrazine cycle in its molecule is the Diquat dibromide. Melo et al. (2014) fractioned fermented broth of Mortierella alpine with different organic solvents and identified the presence of chemical class of alkaloids pyrrolopyrazine: (a) pyrrolo [1,2-a] pyrazine-1,4-dione, hexahydro-3- (2 methylpropyl) and (b) pyrrolo [1,2-a] pyrazine-1,4-dione, hexahydro-3- (phenylmethyl). Other studies indicate that alkaloids as pyridine pyrrole occurs in many endophytes. These compounds have been isolated from species Neotyphodium and Epichloe spp. which are grasses in cold regions, which are used to protect plants against worms and plant pathogens (Nan and Li, 2000; Malinowski et al. 2005; Zhang et al. 2012).

Based on the literature, it is possible that the compound called pyrrolo [1,2-a] pyrazine-1,4-dione, hexahydro-3- (2methylpropyl) presents herbicidal effect on monocotyledons and dicotyledonous plants, but more studies are required to confirm this statement. The highest abundance of this compound was found in T3 where the agitation conditions were minimal (40 rpm) and the highest aeration rate $(3 \mathrm{vvm})$. These results may be related to the oxygen requirement by fungi provided by aeration allowing greater production of the compound of interest. On the other hand, the stirring rate was not considered a limiting factor for the production of these compounds in the studied range, showing that a minimal agitation was sufficient to homogenize the culture medium without negatively impacting the microbial growth. 


\section{Conclusions}

The highest herbicidal activity of fermented broth of Phoma sp. was obtained in $\mathrm{T} 3$ for $C$. sativus and T4 for S. bicolor. In these runs, stirring rate was $40 \mathrm{rpm}$ and $60 \mathrm{rpm}$, respectively, whereas aeration rate was $3 \mathrm{vvm}$. The compound pyrrolo [1,2-a] pyrazine-1,4-dione, hexahydro-3- (2methylpropyl), which is reported in the literature as having herbicidal effect, may be the main metabolite produced by Phoma sp. Secondary metabolites produced by Phoma sp. have herbicidal action on pre-emergence, post-emergence and punctured detached leaves of C. sativus and S. bicolor, and may become an alternative in the future for weed control.

Acknowledgements The authors thank CAPES for the scholarships as well as CNPq and FAPERGS for the financial support of this work.

\section{Compliance with ethical standards}

Conflict of interest The authors declare that there is no conflict of interest.

Open Access This article is distributed under the terms of the Creative Commons Attribution 4.0 International License (http:// creativecommons.org/licenses/by/4.0/), which permits unrestricted use, distribution, and reproduction in any medium, provided you give appropriate credit to the original author(s) and the source, provide a link to the Creative Commons license, and indicate if changes were made.

\section{References}

Andolfi A, Zonno MC, Avolio F, Santini A, Tuzi A, Berestetski A, Vurro M, Evidente A (2013) Chenopodolin: a Phytotoxic Unrearranged ent Pimaradiene Diterpene Produced by Phoma chenopodicola, a Fungal Pathogen for Chenopodium album Biocontrol. J Nat Prod 76:1291-1297

Bailey KL, Pitt WM, Falk S, Derby J (2011) The effects of Phoma macrostoma on nontarget plant and target weed species. Biol Control 58:379-386

Bailey KL, Falk S, Derby JA, Melzer M, Boland GJ (2013) The effect of fertilizers on the efficacy of the bioherbicide, Phoma macrostoma, to control dandelions in turfgrass. Biol Control 65:147-151

Bobylev MM, Bobyleva LL, Cutler HG, Cutler SJ, Strobel GA (2000) Effects of synthetic congeners of the natural product phytotoxins aculosins-1 and -2 on growth of wheat coleoptiles (Triticum aestivum L. cv. Wakeland). In: Anais do X international Symposium on biological control of weeds. Montana State University, Bozeman, Montana, USA. Ed. Neal R. Apencer, pp 209-214

Bracarense AAP, Takahashi JA (2014) Modulation of antimicrobial metabolites production by the fungus Aspergillus parasiticus. Braz J Microbiol 45:313-321

Brasil (2009) Ministério da Agricultura. Regras para análise de sementes. Brasília: Secretaria Nacional de Defesa Agropecuária, p 399

Chutia M, Mahanta JJ, Bhattacharyya N, Bhuyan M, Boruah P, Sharma TC (2007) Microbial herbicides for weed management: prospects, progress and constrains. Plant Pathol J 6:200-218

Evidente M, Cimmino A, Zonno MC, Mais M, Berestetski A, Santoro E, Superchi S, Vurro M, Evidente A (2015) Phytotoxins produced by Phoma chenopodiicola, a fungal pathogen of Chenopodium album. Phytochem 117:482-488
Formentini LR, Norregaard A, Bolic A, Hernandez DQ, Hagemann T, Heins AL, Larsson H, Mears L, Mauricio-Iglesias M, Kruhne U, Gernaey KV (2014) Challenges in industrial fermentation technology research. Biotechnol J 9:727-738

Frans R, Crowley H (1986) Experimental design and techniques for measuring and analyzing plant responses to weed control practices. In: Southern Weed Science Society. Research methods in weed science, Clemson, $3^{\mathrm{a}}$ ed., pp 29-45

Garcia-Ochoa F, Gomez E, Alcon A, Santos VE (2013) The effect of hydrodynamic stress on the growth of Xanthomonas campestris cultures in a stirred and sparged tank bioreactor. Bioproc Biosys Eng 36:911-925

Harding DP, Raizada MN (2015) Controlling weeds with fungi, bacteria and viruses: a review. Front Plant Sci 6:659

Hubbard M, Hynes RK, Bailey KL (2015) Impact of macrocidins, produced by Phoma macrostoma, on carotenoid profiles of plants. Biol Control 89:11-22

Hubbard M, Taylor WG, Bailey KL, Hynes RK (2016) The dominant modes of action of macrocidins, bioherbicidal metabolites of Phoma macrostoma, differ between susceptible plant species. Environ Exp Bot 132:80-91

Kalam S, Khan NA, Singh J (2014) A novel phytotoxic phenolic compound from Phoma herbarum FGCC\#54 with herbicidal potential. Chem Nat Comp 50:644-647

Klaic R, Sallet D, Foletto EL, Jacques RJS, Guedes JVC, Kuhn RC, Mazutti MA (2016) Optimization of solid-state fermentation for bioherbicide production by Phoma sp. Braz J Chem Eng, accepted 2016

Maldonado RR, Burkert JFM, Mazutti MA, Maugeri F, Rodrigues MI (2012) Evaluation of lipase production by Geotrichum candidum in shaken flasks and bench-scale stirred bioreactor using different impellers. Biocatal Agric Biotechnol 1:147-151

Malinowski DP, Belesky DP, Lewis GC (2005) Abiotic stresses in endophyte grasses. In: Craig AR, Charles PW, Donald ES (eds) Neotyphodium in cool-season grasses. Blackwell, Amsterdam, pp 187-199

Mazutti MA, Zabot G, Boni G, Skovronski A, Oliveira D, Di Luccio M, Rodrigues MI, Maugeri F, Treichel H (2010) Mathematical modeling of Kluyveromyces marxianus growth in solid-state fermentation using a packed-bed bioreactor. J Ind Microbiol Biotechnol 37:391-400

Melo IS, Santos SN, Rosa LH, Parma MM, Silva LJ, Queiros SC, Pellizari VH (2014) Isolation and biological activities of an endophytic Mortierella alpine strain from the Antarctic moss Schistidium antarctici. Extremophiles 18:15-23

Nan ZB, Li CJ, (2000) Neotyphodium in native grasses in China and observations on endophyte-host interaction. In: Paul $\mathrm{VH}$, Dapprich PD (eds). Proceedings of the 4th international neotyphodium-grass interactions symposium, Soest, pp 41-50

Serrano-Carreón L, Galindo E, Rocha-Valadéz JA, Holguín-Salas A, Corkidi G (2015) Hydrodynamics, fungal physiology, and morphology. In: Filaments in Bioprocesses, vol. 149, Ed. Springer International Publishing, pp 55-90

Varejão EVV, Demuner AJ, Barbosa CA, Barreto RW (2013) Phytotoxic effects of metabolites from Alternaria euphorbiicola against its host plant euphorbia heterophylla. Quim Nova 36:1004-1007

Vikrant P, Verma KK, Rajak RC, Pandey AK (2006) Characterization of a phytotoxin from Phoma herbarum for management of Parthenium hysterophorus L. J Phytopathol 154:461-468

Yang J, Cao H, Wang W, Zhang L, Dong J (2014) Isolation, identification, and herbicidal activity of metabolites produced by Pseudomonas aeruginosa CB-4. J Integr Agric 13:1719-1726

Zhang X, Li C, Nan Z (2012) Effects of cadmium stress on seed germination and seedling growth of Elymus dahuricus infected with the Neotyphodium endophyte. Sci China Life Sci 55:793-799 